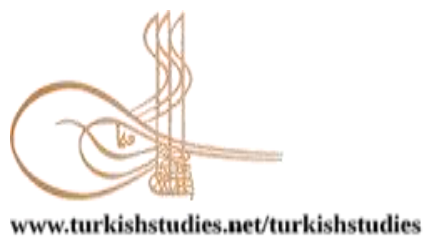

Turkish Studies

Research Article / Araștırma Makalesi

\title{
Öğrencilerin Boş Zaman Aktivitelerine Yönelik Tutum Düzeylerinin Değerlendirilmesi
}

\author{
Evaluation of Students' Attitude Levels towards Leisure Activities
}

\author{
Murat Denkel* - İsa Sağıroğlu** - Cüneyt Taşkın $^{* * *}$ - Harun Ayar****
}

\begin{abstract}
The purpose of this study is to determine the leisure time attitudes of the Faculty of Sport Sciences students and to determine their relationship with some variables. This research was carried out with descriptive scanning model. In addition, it was examined by the Trakya University Social and Human Sciences Research Ethics Committee, and with the decision dated 18.07.2018 and numbered 2018.07.02, it was decided to comply with ethical scientific standards. The universe of the research is composed of students from Trakya University, and the sample consists of students studying at the Kırkpınar Faculty of Sport Sciences. In this study, "Leisure Attitude Scale" is used to as data collection tool to determine individuals' attitudes towards leisure. This scale was developed by Ragheb and Beard in 1982 and adapted to Turkish by Akgül and Gürbüz (2011). The attitudes of participants towards recreational activities were measured according to gender, department, study and family income variables. The data obtained were analyzed using SPSS 25 package program. Descriptive statistical methods were used to analyze the data. When the values of Leisure Attitude Scale normality test Kolmogorav Smirnof, Levene, Kurtosis and Skewness are examined, it is seen that the data do not show a normal distribution. Kruskal-Wallis and Mann Whitney U tests, which are non-parametric tests, were applied to determine the difference between attitudes towards leisure and demographic variables. Post-hoc values were examined to determine the dimensions with which there was a difference. According to the affective, cognitive, behavioral and all scale sub-dimensions of the participants' Leisure Attitude Scale; statistically significant difference was found in all of the gender variable, the affective, behavioral and all scale of the department variable, and the behavioral and income variable of the study $(\mathrm{P}<0.05)$.
\end{abstract}

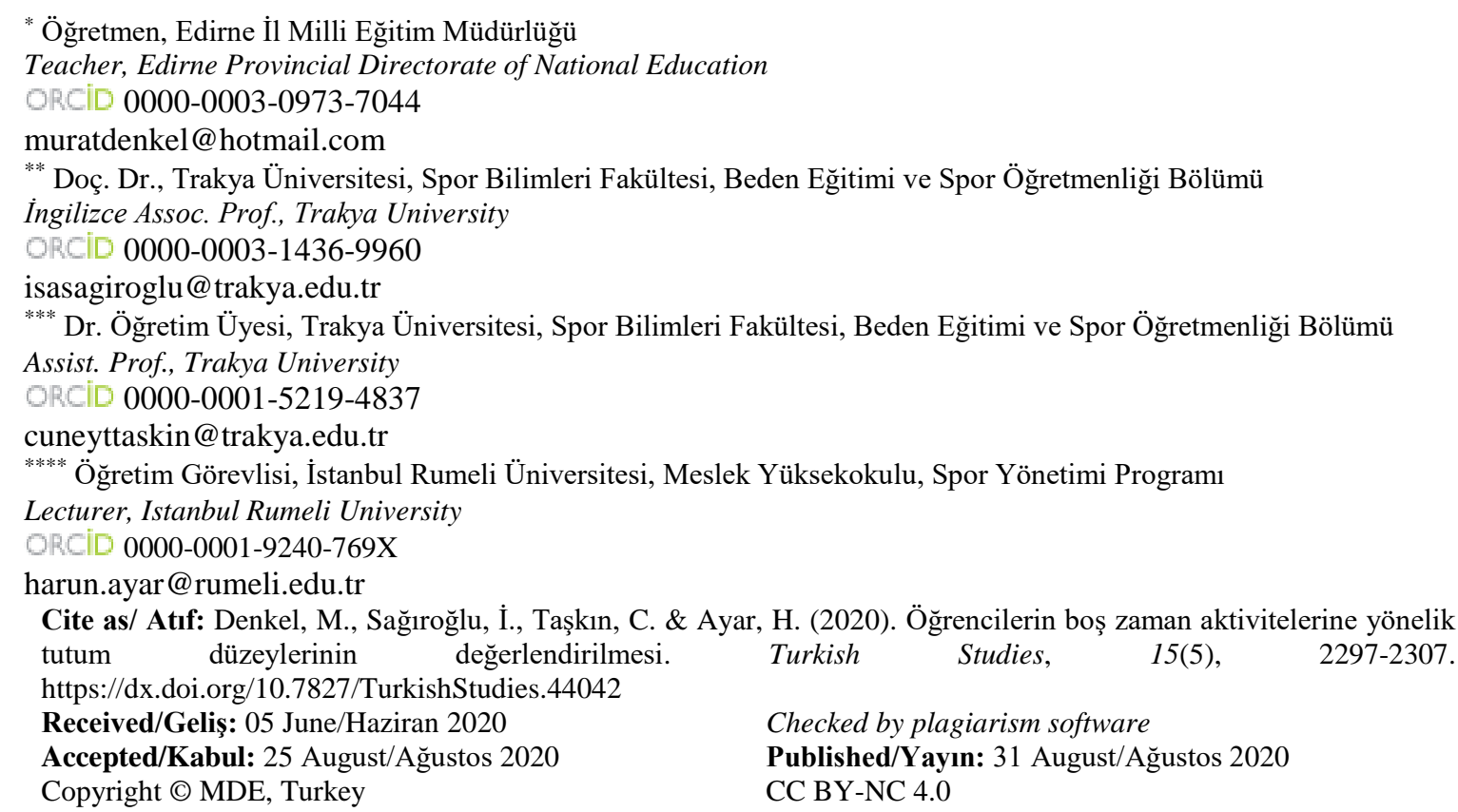


Structured Abstract: Introduction: In short, leisure time is the time when the person is not working, is left out of life obligations and responsibilities, and one can spend on his own will. Recreation is also the evaluation of leisure time with various activities (Karaküçük, 1999). Due to the increase in the socio-economic and cultural levels of people today, people have started to evaluate their time for activities that are important and beneficial for them. Thus, people with increased awareness, level of consciousness, free time and disposable income started to seek the best use of their spare time (Gümüş, 2018). The issue of how leisure time is valued affects people's well-being. The physical environment and social structure of individuals play an important role in the formation or shaping of leisure attitudes. It is known that developments in technology also cause the formation and change of leisure attitudes (Akgül, 2011).

\section{Purpose}

The aim of this study is to determine the attitudes of students, who study at Trakya University Kırkpınar Faculty of Sport Sciences, towards recreation studies and to determine its relation with various variables. In this study, the attitudes of university students studying at the Faculty of Sport Sciences towards leisure activities are examined. Hopefully, it will guide the future studies in this field.

G1: There is a difference between the attitudes of the participants according to gender variables.

G2: There is a difference in the attitudes of the participants according to their department variables.

G3: There is a difference in leisure attitudes according to the working variables of the participants.

G4: There is a difference between the attitudes of the participants according to the family income variables.

\section{Method}

The screening method used in the research is the method in which the opinions of the participants related to a subject or event or their characteristics such as interest, skill, ability and attitude are determined. The research was carried out using a descriptive researched method. The descriptive research method is the research approach that aims to examine a situation existing in the past or still as it exists. The events, individuals or objects that are the subject of the research are tried to be defined in their own conditions and as they are. The important thing is to be able to observe and determine them appropriatelywithout any intervention. (Karasar, 2005). Indeed, screening research aims to collect data to determine certain characteristics of a group. In order to determine the attitudes of the students studying at the Faculty of Sport Sciences towards leisure, to enable students to participate more in their leisure activities and to schedule a higher quality and more efficient time, a previously created scale was used.

The data were transferred to SPSS 25.0 program for statistical evaluation.

Descriptive statistics methods were used in the analysis of demographic data. Kruskal-Wallis and Mann Whitney U tests, one of the non-parametric tests, were used to determine the difference between leisure attitudes and demographic variables. Post-hoc values were examined to determine the dimensions in variability.

\section{Results}

According to the leisure time attitude scale, it is obvious that behavioral sub-dimension of the participants is the least while the cognitional attitude level is the highest. There is a statistically significant difference in affective, cognitive and behavioral sub-dimentions of the leisure time attitude scale. It was determined that these differences are in the affective and behavioral sub-dimensions, as well as in the teachingcoaching and teaching-recreation departments, between the leisure-attitude scale in general and in the behavioral sub-dimension, teaching-coaching and teaching recreation departments. When the leisure attitude levels of the participants are examined according to their working status, it is found that there is no statistically significant difference in the leisure, affective and cognitive sub-dimensions of the scale.

However, according to the study status variable, there is a statistically significant difference in leisure behavior scale and behavioral sub-dimension. These differences are among students who do not work with full-time at the behavioral sub-dimension of the leisure attitude scale. Considering the leisure attitude levels of the participants according to their family income, it is clear that there is no statistically significant difference in their affective, cognitive and behavioral sub-dimensions. 
There is a statistically significant difference across the leisure attitude scale according to the family income variable. These differences are between those who have a family income below 2000 TL and those who have a family income of $2000 \mathrm{TL}-4000 \mathrm{TL}$ in the leisure attitude scale.

Keywords: Sports, Recreation, Leisure, Attitude, Event

Öz: Bu araştırma, Spor Bilimleri Fakültesinde okumakta olan öğrencilerin boş zaman tutum düzeylerinin belirlenerek, bazı değişkenlerle arasındaki ilişkiyi ortaya koymaktır. Bu araştırma betimsel tarama modeli ile gerçekleştirildi. Ayrıca Trakya Üniversitesi Sosyal ve Beşeri Bilimler Araştırmaları Etik Kurulu tarafından incelenmiş, 18.07.2018 tarih ve 2018.07.02 nolu karar ile etik bilimsel standartlar açısından uygunluğuna karar verilmiştir. Çalışmanın evrenini Trakya Üniversitesinde öğrenim gören öğrenciler oluştururken, örneklemini ise Kırkpınar Spor Bilimleri Fakültesinde öğrenim gören öğrenciler oluşturmaktadır. Araştırmada katılımcıların boş zaman tutumlarını belirlemek amacı ile ilgili veri toplama aracı olarak Ragheb ve Beard (1982) yılında geliştirilen ve Türkçeye uyarlaması Akgül ve Gürbüz (2011) tarafından yapılan "Boş Zaman Tutum Ölçeği” (BZTÖ) kullanılmıştır. Katılımcıların, bölüm, cinsiyet, aile gelir ve çalışma değişkenlerine göre rekreatif etkinliklere karşı tutumları belirlenirken, ortaya çıkan veriler SPSS 25 paket programı uygulanarak analiz edilmiştir. Verilerin analizinde betimsel istatistik yöntemleri uygulanmıştır. Boş Zaman Tutum Ölçeği normallik testi Kolmogorav Smirnof, Levene, Basıklık (Kurtosis) ve Çarpıklık (Skewness) değerlerine bakıldığında verilerin normal dağılım göstermediği görülmektedir. Boş zamana yönelik tutumların demografik değişkenler ile arasındaki farklılığı tespit etmeye yönelik non-parametrik testlerden Kruskal-Wallis ve Mann Whitney $U$ testleri uygulanmıştır. Farklılığın olduğu değişkenliklerde ise hangi boyutlar ile olduğunu tespit etmeye yönelik Post-hoc değerlerine bakılmıştır. Katılımcıların, BZTÖ’nin, bilişsel, duyuşsal, davranışsal ve tüm ölçeğe göre; cinsiyet değişkeninin tümünde, bölüm değişkeninin duyuşsal, davranışsal ve tüm ölçeğinde, çalışma değişkeninin davranışsal ve gelir değişkeninin tüm ölçeğinde istatistiki açıdan anlamlı farklılık tespit edilmiştir $(\mathrm{P}<0,05)$.

Anahtar Kelimeler: Spor, Rekreasyon, Boş Zaman, Tutum, Etkinlik

\section{Giriş}

Boş zaman faaliyetleri, insanları çalışma sürelerinden ve fizyolojik ihtiyaçlarından geriye kalan zamanlarında aktif olmak için belirledikleri aktiviteler ve sosyal, zihinsel ve fiziksel bileşenleri kapsayan çok yönlü bir kavram olarak tanımlanır (Broadhurst, 2001). Seçilen bu aktiviteler, grup veya bireysel şekilde, bazı toplumsal, fiziki ve duygusal davranışları kazanmak için tamamen kendi isteği ile katılımdan herhangi bir etkinlik türünü kapsayabilir. Bu kavram, bireyde kişisel gelişim, tatmin, doyum ve iyi olmaya yönelik gelişen bir duygudur (Kılbaş, 2010).

Boş zaman kavramını kısa bir şekilde tanımlamak gerekirse Karaküçük (1995), bireylerin iş hayatı, zorunlu ihtiyaçlar ve sorumluluklarından ayrı, kişinin tamamen kendi hür ve özgür iradesi ile harcayabileceği zamandır. Rekreasyon ise, boş zaman içerisinde gerçekleştirilen etkinliklerin büyük bir kısmını oluşturmaktadır (Karaküçük, 1999).

Günümüz çağında boş zaman okullarda, "Eğitimin amaçlarını gerçekleştirmek, öğrencilerin sosyal gelişimi, toplumsal statü kazanması ve kültürler arası aktarım ile farklı kültürlerin birbirleriyle kaynaşması için ihtiyaç arz etmektedir" (Karataş, 2006).

Hayatlarının büyük bir bölümünü beraber geçiren üniversite öğrencileri ve gençler; "aynı toplumun bireyleri olmalarına karşın; içinde yaşadıkları fiziki çevre özelliklerine, aldıkları eğitime, üretime katılıp katılmayışlarına, ailelerinin sosyo-kültürel ve sosyo-ekonomik yapılarına göre farklı alt kültür donanımlarına sahiptir. Bu farklılık, gençler ve üniversite öğrencilerinin boş zaman değerlendirme ile ilgili tutum ve davranışlarına yansımaktadır”' (Aslan, 2000).

Boş zaman duyuşsal, bilişsel ve davranışsal olmak üzere üç boş zaman tutum öğesi vardır. 
Boş zamana yönelik tutumların bilişsel öğesi; bireylerin boş zaman aktivitelerine yönelik genel bilgi ve inanç, boş zamanda mutluluk, sağlık, iş hayatı gibi kavramlarla olan ilişkilerinin bilinmesi, boş zamanın karakteristik özellikleri ve niteliğinin belirlenmesi, bireye kazandırdığı faydaların farkında olunmasından oluşmaktadır (Ragheb ve Beard, 1982).

Bireylerin boş zamana karşı tutumlarının duyuşsal boyutuna göre; katılım gösterdikleri aktivitelere göre tecrübelerinin değerlendirilmesi, bireylerin bu aktivitelerden keyif alıp almama durumlarını, boş zaman aktivitelerine katılım süresince hissettikleri duyguları açıklamaktadır (Ragheb ve Beard, 1982).

Bireylerin boş zamana karşı tutumlarının davranışsal boyutuna göre; bireyler boş zaman aktivitelerine yönelik davranışsal eğilimleri, boş zaman aktivitelerine hem geçmişte hem de bugün katılım sıklı̆̆ını içermektedir (Ragheb ve Beard, 1982).

$\mathrm{Bu}$ araştırmanın amacı, Trakya Üniversitesi Kırkpınar Spor Bilimleri Fakültesi öğrencilerinin rekreasyonel etkinliklere karşı tutumlarını ölçmek ve katılımcıların bazı demografik özelliklerine göre arasındaki farklılıkları tespit etmektir. Bu çalışma, Spor Bilimleri Fakültesi'nde öğrenimine devam eden öğrencilerin boş zaman etkinliklerine yönelik tutumlarının tespit edilmesi ve bu alanda yapılacak çalışmalara yol göstermesi açısından önemlidir.

\section{Hipotezler:}

H1: Katılımcıların cinsiyet değişkenlerine göre boş zaman tutumlarına yönelik fark vardır.

H2: Katılımcıların bölüm değişkenlerine göre boş zaman tutumlarına yönelik farkvardır.

H3: Katılımcıların çalışma değişkenlerine göre boş zaman tutumlarına yönelik fark vardır.

H4: Katılımcıların aile geliri değişkenlerine göre boş zaman tutumlarına yönelik fark vardır.

\section{Yöntem}

Mevcut çalışmada konu veya olaylar ile ilişkili katılımcılardan görüş, beceri, ilgi ve tutum gibi özelliklerinin tespit edildiği bir tarama modeli uygulandı. Çalışma betimsel tarama modeli yöntemi ile gerçekleştirildi. Betimleyici İstatistik yöntemlerinden tarama modeli, gerçekleşmiş veya şu anda gerçekleşen bir durumu gerçekleştiği halde incelemeyi öngören bir araştırma yaklaşımıdır. Araştırması planlanan olay, nesne veya birey kendi koşullarında olduğu gibi tespit edilmeye çalışılır. Herhangi bir şekil değişikliği veya etkileme gibi durum söz konusu olmaz. Dikkat edilmesi gereken uygun bir şekilde gözlemleyip, ortaya çıarmak (Karasar, 2005). Farklı bir ifade ile, belirli bir grubun bazı özelliklerini belirlemek üzere verilerin toplanmasını hedefleyen araştırmalara tarama modeli denilmektedir. Spor Bilimler Fakültesi öğrencilerinin boş zaman tutumlarını tespit edebilmek, boş zaman etkinliklerine aktif katılabilmeleri ve kaliteli bir zaman planı yapabilmelerine katkı sağlamak üzere önceden hazırlanmış ve geçerliliği, güvenirliği yapılmış ölçek kullanıldı. Bu çalışma, Trakya Üniversitesi Sosyal ve Beşeri Bilimler Araştırmaları Etik Kurulu tarafından incelenmiş, 18.07.2018 tarih ve 2018.07.02 nolu karar ile etik bilimsel standartlar açısından uygunluğuna karar verilmiştir.

\section{Evren ve Örneklem}

Çalışmanın evrenini Kırkpınar Spor Bilimleri Fakültesi'nde öğrenim gören 1230 öğrenci oluşturmaktadır. Örneklem sayısını belirlemede $\% 95$ güven aralığına göre hesaplanmış ve 288 öğrenci olarak belirlenmiştir. Belirlenen 288 öğrenci örneklem alma yöntemlerinden uygun örnekleme yöntemine göre belirlenmiştir. Uygun / Kazara Örnekleme; zaman, para ve işgücü açısından var olan sınırlılıklar nedeniyle örneklemin kolay ulaşılabilir ve uygulama yapılabilir birimlerden seçilmesi anlamına gelmektedir (Büyüköztürk, vd. 2019). Örneklem grubu 2014-2018 yılları arasında Spor Bilimleri Fakültesi'nde öğrenim gören öğrencilerden 1-4 sınıfları arasında Beden Eğitimi ve Spor Öğretmenliği, Antrenörlük Eğitimi, Rekreasyon ve Spor Yöneticiliği 
bölümleri öğrencileri arasından seçilerek belirlendi. Belirlenen bu öğrencilere "Boş Zaman Tutum Ölçeğì" anket yöntemi ile uyguland. Toplanan veriler SPSS 25.0 paket programı ile analiz edildi.

\section{Verilerin Toplanması ve Veri Toplama Araçları}

Ölçme aracı Kırkpınar Spor Bilimleri Fakültesi öğrencilerine uygulanmak üzere öğrencilerin en uygun vakitleri tespit edildi. Öğrencilerin uygun vakitleri tespit edildikten sonra ölçeği uygulamadan önce üniversite yetkilileri tarafından gerekli izinler alındı. Ölçek formu uygulama aşamasında araştırmayı yürüten kişi tarafından bizzat öğrencilere dağıtıldı. Öğrencilerin "Boş Zaman Tutum Ölçeği'ndeki sorulara karşı cevapları, araştırmacı tarafından Microsoft Excel programına aktarılarak, analize hazır duruma getirildi. Ragheb ve Beard (1982) tarafından geliştirilen Boş Zaman Tutum Ölçeği'nin Türkçe geçerlilik ve güvenirlik çalışmasını Akgül ve Gürbüz (2011) gerçekleştirmiş ve kültürümüze uygun olduğu tespit etmiş̧lerdir. 36 madde ve 3 alt boyut (bilişsel, duyuşsal ve davranışsal)'tan oluşan 5'li likert tipi ölçek (Tamamen katılıyorumdan, hiç katılmıyoruma kadar) düzenlenmiştir. Yine Akgül ve Gürbüz (2011) tarafindan Cronbach Alpha güvenirlik testi yapılarak bilimsel çalışmalara uygun hale getirilmiştir.

\section{İstatistiksel Analiz}

Veriler, istatistiksel olarak değerlendirilmek üzere SPSS 25.0 programına aktarılmıştır.

Demografik verilerin analizinde betimsel istatistik yöntemleri uygulanmıştır. Boş Zaman Tutum Ölçeği normallik testi Kolmogorav Smirnof, Levene, Basıklık (Kurtosis) ve Çarpıklık (Skewness) değerlerine bakıldığında verilerin normal dağılım göstermediği görülmektedir. Boş zamana yönelik tutumların demografik değişkenler ile arasındaki farklılığı tespit etmeye yönelik non-parametrik testlerden Kruskal-Wallis ve Mann Whitney U testleri uygulanmıştır. Farklılığın olduğu değişkenliklerde ise hangi boyutlar ile olduğunu tespit etmeye yönelik Post-hoc değerlerine bakılmıştır.

\section{Bulgular}

Tablo 1. Katılımcıların demografik özellikleri

\begin{tabular}{|c|c|c|c|}
\hline & & $\mathbf{N}$ & $\%$ \\
\hline \multirow{3}{*}{ Cinsiyet } & Erkek & 150 & 49,2 \\
\hline & Kadın & 155 & 50,8 \\
\hline & Toplam & 305 & 100,0 \\
\hline \multirow{5}{*}{ Bölüm } & Öğretmenlik & 52 & 17,0 \\
\hline & Antrenörlük & 55 & 18,0 \\
\hline & Yöneticilik & 100 & 32,8 \\
\hline & Rekreasyon & 98 & 32,1 \\
\hline & Toplam & 305 & 100,0 \\
\hline \multirow{4}{*}{ Aile Geliri } & $2000 \mathrm{TL}$ aşağıs 1 & 91 & 29,8 \\
\hline & $2000-4000 \mathrm{TL}$ & 124 & 40,7 \\
\hline & 4000 TL üzeri & 90 & 29,5 \\
\hline & Toplam & 305 & 100,0 \\
\hline \multirow{4}{*}{ Çalışma } & Tam zamanlı & 28 & 9,2 \\
\hline & Yarı zamanlı & 118 & 38,7 \\
\hline & Çalışmıyor & 159 & 52,1 \\
\hline & Toplam & 305 & 100,0 \\
\hline
\end{tabular}

Tablo 1 incelendiğinde, çalışmaya katılan gönüllü öğrencilerin \%49,2'sinin erkek, $\% 50,8$ 'inin kadın olduğu, \%17'sinin öğretmenlik, \%18'inin antrenörlük, \%32,8'inin yöneticilik, \%32,1'inin rekreasyon bölümlerinde öğrenim gördüğü, \%29,8'inin 2000TL aşağıS1, \%40,7'sinin 2000 - 4000TL, \%29,5'inin 4000TL ve üzeri gelir düzeye sahip olduğu, \%9,2'sinin tam zamanl,, \%38,7'sinin yarı zamanlı, \%52,1'inin herhangi bir işte çalışmadığı görülmektedir. 
Tablo 2. Katılımcıların boş zaman tutum ölçeğine verdiği cevapların betimsel analizi

\begin{tabular}{cccc}
\hline Alt Boyutlar & Min & Max & Mean \pm Ss \\
\hline Duyuşsal & 1,00 & 5,00 & $4,07 \pm 0,70$ \\
\hline Bilişsel & 1,00 & 5,00 & $4,16 \pm 0,61$ \\
\hline Davranışsal & 1,00 & 5,00 & $3,92 \pm 0,78$ \\
\hline Boș Zaman Tutum Genel & 1,00 & 5,00 & $4,05 \pm 0,64$ \\
\hline
\end{tabular}

Tablo 2 incelendiğinde, katılımcıların boş zaman tutum ölçeği, duyuşsal alt boyutu ortalaması $4,07 \pm 0,70$, bilişsel alt boyutu ortalaması $4,16 \pm 0,61$, davranışsal alt boyutu ortalaması 3,92 $\pm 0,78$, boş zaman tutum ölçeği genel ortalaması $4,05 \pm 0,64$, olarak tespit edilmiştir. Boş zaman tutum ölçeği ve alt boyutlarının ortalamalarına bakıldığında, katılımcıların davranışsal alt boyutu ortalaması en az iken, en çok bilişsel tutum düzeyi ortalamasının yüksek olduğu görülmektedir.

Tablo 3. Katılımcıların cinsiyetlerine göre boş zaman tutum düzeylerinin değerlendirilmesi

\begin{tabular}{|c|c|c|c|c|c|}
\hline Boyutlar & Cinsiyet & $\mathbf{N}$ & Sira Ort. & $\mathbf{U}$ & $\mathbf{P}$ \\
\hline \multirow{3}{*}{ Duyuşsal } & $\operatorname{Kadın}^{1}$ & 155 & 170,60 & & \\
\hline & Erkek $^{2}$ & 150 & 134,81 & 8896,50 &, $000 *$ \\
\hline & Kadın $^{1}$ & 155 & 172,91 & & \\
\hline \multirow[t]{2}{*}{ Bilişsel } & Erkek $^{2}$ & 150 & 132,43 & 8539,00 &, $000 *$ \\
\hline & Kadın $^{1}$ & 155 & 176,09 & & \\
\hline Davranışsal & Erkek $^{2}$ & 150 & 129,14 & 8046,00 &, $000 *$ \\
\hline \multirow[t]{2}{*}{ Boş Zaman Tutum Genel } & Kadın $^{1}$ & 155 & 175,85 & & \\
\hline & Erkek $^{2}$ & 150 & 129,39 & 8083,00 &, $000 *$ \\
\hline
\end{tabular}

Tablo 3 incelendiğinde, katılımcıların cinsiyetlerine göre boş zaman tutum düzeyleri duyuşsal, bilişsel, davranışsal alt boyutlarında ve boş zaman tutumu genelinde anlamlı farklılık görülmüştür $(\mathrm{p}<0,05)$.

Tablo 4. Katılımcıların bölümlerine göre boş zaman tutum düzeylerinin değerlendirilmesi

\begin{tabular}{|c|c|c|c|c|c|c|c|}
\hline Boyutlar & Bölümler & $\mathbf{N}$ & Sira Ort. & sd & $\mathbf{X}^{2}$ & $\mathbf{p}$ & Fark \\
\hline \multirow{4}{*}{ Duyuşsal } & Öğretmenlik ${ }^{1}$ & 52 & 115,19 & \multirow{16}{*}{3} & \multirow{4}{*}{12,200} & \multirow{4}{*}{,007* } & \multirow{4}{*}{$\begin{array}{l}1-3 \\
1-4\end{array}$} \\
\hline & Antrenörlük ${ }^{2}$ & 55 & 152,79 & & & & \\
\hline & Yöneticilik ${ }^{3}$ & 100 & 161,37 & & & & \\
\hline & Rekreasyon $^{4}$ & 98 & 164,64 & & & & \\
\hline \multirow{4}{*}{ Bilişsel } & Öğretmenlik ${ }^{1}$ & 52 & 140,43 & & & & \\
\hline & Antrenörlük ${ }^{2}$ & 55 & 166,35 & & & & \\
\hline & Yöneticilik ${ }^{3}$ & 100 & 143,95 & & 4,275 & 233 & - \\
\hline & Rekreasyon $^{4}$ & 98 & 161,42 & & & & \\
\hline \multirow{4}{*}{ Davranışsal } & Öğretmenlik ${ }^{1}$ & 52 & 122,63 & & \multirow{4}{*}{15,281} & \multirow{4}{*}{,002* } & \multirow{4}{*}{$\begin{array}{l}1-2 \\
1-4\end{array}$} \\
\hline & Antrenörlük ${ }^{2}$ & 55 & 176,91 & & & & \\
\hline & Yöneticilik ${ }^{3}$ & 100 & 140,47 & & & & \\
\hline & Rekreasyon $^{4}$ & 98 & 168,48 & & & & \\
\hline \multirow{4}{*}{$\begin{array}{c}\text { Boş Zaman Tutum } \\
\text { Genel }\end{array}$} & Öğretmenlik ${ }^{1}$ & 52 & 123,12 & & \multirow{4}{*}{10,678} & \multirow{4}{*}{, $014 *$} & \multirow{4}{*}{$\begin{array}{l}1-4 \\
1-2\end{array}$} \\
\hline & Antrenörlük ${ }^{2}$ & 55 & 170,52 & & & & \\
\hline & Yöneticilik ${ }^{3}$ & 100 & 146,56 & & & & \\
\hline & Rekreasyon $^{4}$ & 98 & 165,60 & & & & \\
\hline
\end{tabular}

Tablo 4'te katılımcıların okudukları bölümlere göre boş zaman tutum düzeyleri incelendiğinde, bilişsel alt boyutunda istatistiksel açıdan anlamlı bir farklılığın olmadığı tespit edilmiştir $(p>0,05)$. Boş zaman tutum ölçeği, duyuşsal ve davranışsal alt boyutlarında ise bölüm değişkenine göre istatistiksel açıdan anlamlı bir farklılık tespit edilmiştir $(p<0,05)$. Bu farklılıkların 
duyuşsal ve davranışsal alt boyutlarında da, öğretmenlik-antrenörlük ile öğretmenlik-rekreasyon bölümlerinde olduğu, boş zaman tutum ölçeği geneli ve davranışsal alt boyutunda öğretmenlikantrenörlük ile öğretmenlik rekreasyon bölümleri arasında olduğu tespit edilmiştir.

Tablo 5. Katılımcıların çalışma durumlarına göre boş zaman tutum düzeylerinin değerlendirilmesi

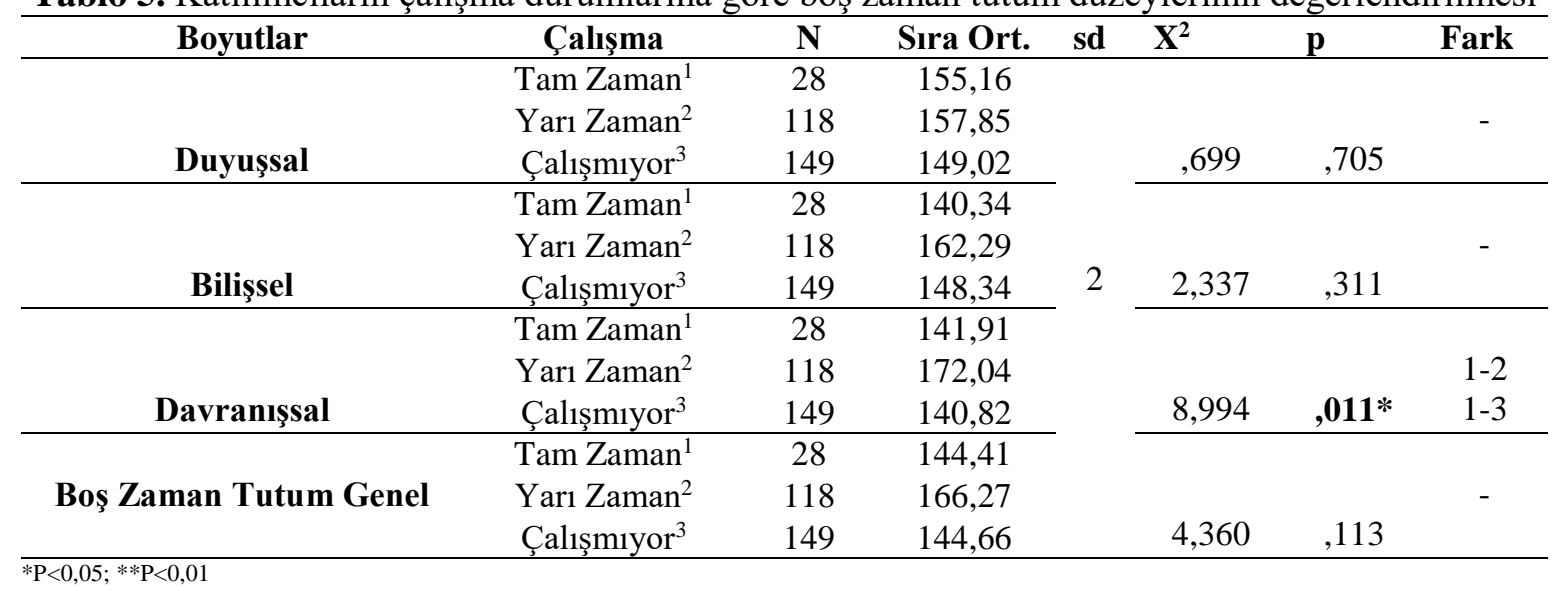

Tablo 5'te katılımcıların çalışma durumlarına göre boş zaman tutum düzeyleri incelendiğinde, boş zaman tutum ölçeği geneli, duyuşsal ve bilişsel alt boyutlarında istatistiksel açıdan anlamlı bir farklılığın olmadığı tespit edilmiştir ( $>00,05)$. Boş zaman tutum ölçeği, davranışsal alt boyutunda ise çalışma durumu değişkenine göre istatistiksel açıdan anlamlı bir farklılık tespit edilmiştir $(\mathrm{p}<0,05)$. Bu farklı1ıkların boş zaman tutum ölçeği davranışsal alt boyutunda tam zamanlı çalışan ile çalışmayan öğrenciler arasında olduğu tespit edilmiştir.

Tablo 6. Katılımcıların aile gelirine göre boş zaman tutum düzeylerinin değerlendirilmesi

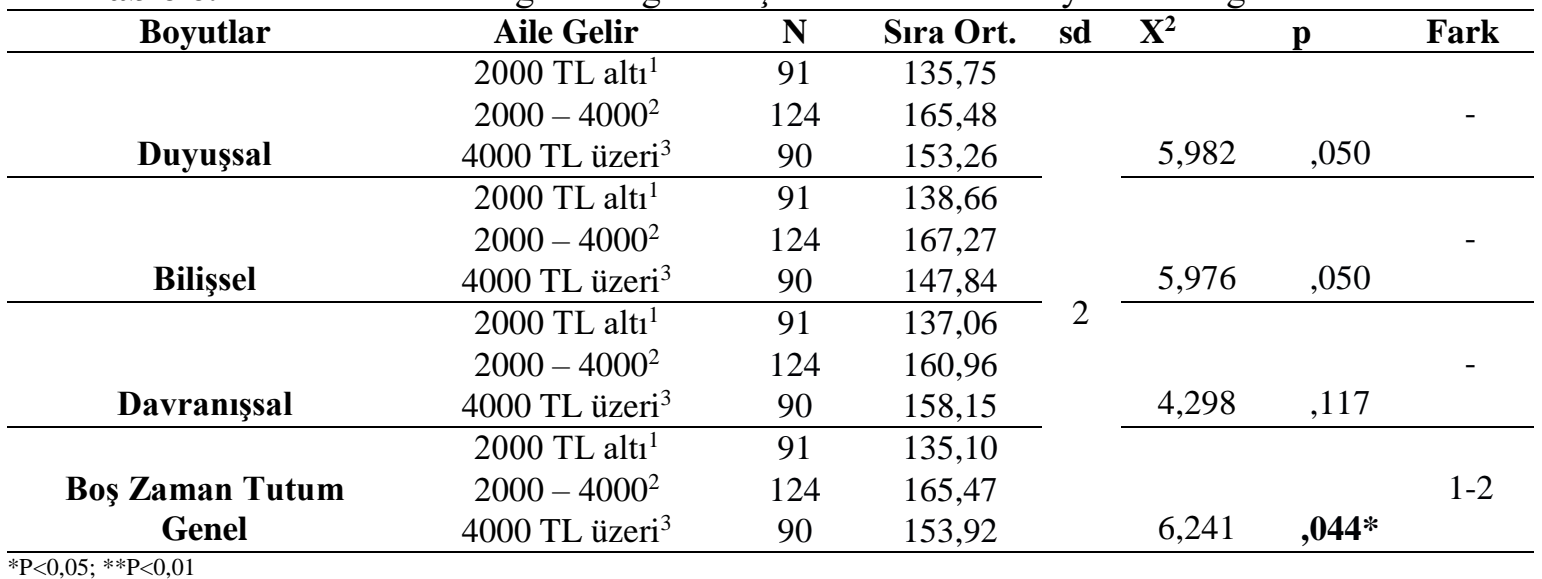

Tablo 6'da katılımcıların aile gelirlerine göre boş zaman tutum düzeyleri incelendiğinde, duyuşsal, bilişsel ve davranışsal alt boyutlarında istatistiksel açıdan anlamlı bir farklılığın olmadığı tespit edilmiştir ( $p>0,05)$. Boş zaman tutum ölçeği genelinde, aile geliri değişkenine göre istatistiksel açıdan anlamlı bir farklılık tespit edilmiştir $(\mathrm{p}<0,05)$. Bu farklılıkların boş zaman tutum ölçeğinde 2000TL altı aile gelir düzeyine sahip olanlar ile 2000 - 4000TL aile gelir düzeyine sahip olanlar arasında olduğu tespit edilmiştir.

\section{Tartışma ve Sonuç}

Katılımcıların boş zaman tutum düzeylerinde, cinsiyet değişkeni için tutumun tüm boyutlarında, bölüm değişkeninin davranışsal, duyuşsal ve genel tutum düzeyinde, çalışma durumları değişkeninin davranışsal alt boyutunda ve gelir düzeyi değişkeninin genel boş zaman tutumunda 
farkl11ık tespit edilmiştir. Mevcut çalışma ile paralel olarak Sanin (2019), üniversite öğrencilerinin boş zaman tutumlarının cinsiyetlerine göre aralarında farklılıklarının olmadığını tespit etmişlerdir. Mevcut çalışma ile farklı olarak Yıldıran (2019), üniversite öğrencilerinin boş zaman tutumlarının cinsiyetlerine göre aralarında farklılıklarının olduğunu tespit etmiştir. Akgül (2011)'ün, "Farklı Kültürlerdeki Bireylerin Boş Zaman Aktivitelerine Yönelik Tutumlarının Değerlendirilmesi: Ankara- Londra Örneği”" adlı araştırmasında katılımcıların demografik özelliklerine göre cinsiyet değişkeni açısından değerlendirmesinde mevcut çalışmamızla benzelik gösterdiği görülmektedir. "Boş zaman tutumu, Ankara' daki bireylerin cinsiyetlerine göre genel olarak farklılık göstermektedir. Bununla beraber, Londra'daki bireylerin cinsiyetlerine göre ise genel anlamda farklıl1k göstermemektedir. Yani, Londra'da bireylerin kadın ya da erkek olmasının, bireyin boş zaman tutumlarında herhangi bir değişikliğe sebep olmazken, Ankara' daki bireylerde bu durumun tam tersi şekilde olduğu görülmektedir. Ayrıca, Ankara'daki erkek bireylerin boş zaman tutumlarının, kadınlara göre daha olumlu olduğu söylenebilir. Bu durumun sebebi, Türkiye gibi geleneksel denilebilecek toplumlarda kadınlar ve erkekler arasındaki rollerin örf ve adetlerle birbirinden ayrılsa da İngiltere gibi toplumlarda cinsiyet farklıllğının, insanların tutum ve davranışlarına daha az yansıdığı şeklinde olabilir" (Akgül, 2011). Örnek vermek gerekirse, her aktivitenin aynı güç ile yapılıyor olmaması, kadınların ve erkeklerin farklı toplumsal deneyimlere sahip olması ve kadınların farkl1 sosyo-ekonomik seviyelere sahip olmasıla genellikle ev merkezli konumda olması gibi nedenler yer alabilir (Wilson, 1980;).

Mevcut çalışmadan farklı olarak Bakay’ın “Öğrencilerinin Boş Zaman Faaliyetlerine Yönelik Tutumun Belirlenmesi” isimli araştırmasında; öğrencilerin boş zaman etkinliklerine yönelik, duyuşsal, bilişsel ve davranışsal boyutlarındaki tutumlarının cinsiyetlerine göre farklılaşmadığı tespit edilmiştir (Bakay, 2018; 51). Akyüz, (2015) Londra'da yaşayan bireyler üzerinde yaptığ araştırmada, katılımcıların cinsiyetlerine göre boş zaman tutum düzeylerinde herhangi bir önemli seviyede farklılık tespit etmemiştir. Deng ve ark (2005), Kanada'da ikamet eden İngiliz ve Çinli vatandaşların boş zaman tutum düzeylerini belirlemek için yaptığı çalışmada, katılımçların cinsiyetlerine göre tutum düzeylerinde bir farkl11ık tespit edilmediği görülmektedir.

Chung ve ark (2002), Tayvan ve Amerika'da yapmış olduğu çalışmada lise öğrencilerinin boş zaman tutumlarında cinsiyet değişkenine göre anlamlı farklılıklar tespit etmişlerdir. Araştırma sonucuna göre Amerikalı öğrenciler, Tayvanlı öğrencilerden daha çok boş zaman tutum düzeyine oldukları görülmüştür. Binbaşığlu ve Tuna (2014)'da üniversite öğrencilerinin cinsiyetlerine göre boş zaman tutum düzeylerinde anlamlı farklılık tespit etmişlerdir. Karakullukçu (2020), öğretmen adaylarının BZTÖ puanlarının cinsiyetlerine göre anlamlı bir şekilde farklılaştığını tespit etmiştir. $\mathrm{Bu}$ bulgu sonucunda öğretmen adaylarının kadın ya da erkek olmalarının, boş zaman tutumlarını farklı şekilde etkilediğini ortaya koymuştur. Yapılan çalışmalar arasında mevcut çalışma ile cinsiyet değişkenine göre paralellik gösteren ve göstermeyen çalışmalar olduğu görülmektedir.

$\mathrm{Bu}$ çalışmada öğrencilerin gelir düzeylerine göre boş zaman tutum düzeylerinde anlamlı farklı1ık görülmektedir. Mevcut çalışmadan farklı olarak Akgül, (2011)'in çalışmasında da Ankara ve Londra'da yaşayan katılımcıların gelir düzeylerine göre de farklılaşmadığı belirtilmiştir. Öğrenciler genellikle kurslara katılım, akraba-arkadaş ziyaretleri sıklıklarında farklılıklar tespit edilmiştir. Bu duruma göre; Londra'daki bireylerin sık s1k arkadaş-akraba ziyareti ve kurslara yöneldikleri anlaşılmaktadır. Böylece, Londra'daki öğrencilerin sosyal faaliyetlere yönelik katılımlarının daha fazla olduğu şeklinde yorumlanabilir (Akgül, 2011).

Önal (2017), Öğrencilerin boş zaman tutumları ile boş zaman aktivitelerine katılımını engelleyen faktörler üzerinde yaptığı çalışmada, gelir düzeyi düşük olan bireyler aktivitelere katılımda eğitim verecek kişilerin olmamasından ve aktiviteleri nerede yapacağını bilmeyişinden dolayı, gelir düzeyi yüksek olan kişilere oranla daha fazla etkilendikleri sonucuna ulaşmıştır. Akyüz (2015)'ün 'Üniversite Öğrencilerinin Boş Zaman Faaliyetlerine Yönelik Tutumlarının İncelenmesi: 
Bartın Üniversitesi Örneği” isimli çalışma ile benzer şekilde; öğrencilerin gelir düzeylerinde farklılaşıp farklılaşmadığını belirlemek için, okudukları ilde ne kadar gelire sahip olduklarına yönelik oluşturulan puan ortalamalarına bakıldığında boş zaman tutum düzeyinin geneli ve alt boyut (bilişsel, davranışsal ve duyuşsal) anlamlı düzeyde farklılık görülmemiştir (Akyüz, 2015). Gürbüz ve ark (2011) katılımcıların \%80,8'inin boş zamanlarını "dinlenmeyi” tercih ederek değerlendirdiklerini belirterek, aktif olmayan rekreatif faaliyetlere katılımın, aktif olanlardan fazla olduğuna vurgu yapmaktadır. Aynı zamanda, katılımcıların boş zamanlarında çok az tercih ettikleri faaliyet türünün ise turistik etkinlikler $(\% 7,8)$ olduğunu belirtmişlerdir. Bu durum ise katılımcıların gelir seviyelerinin düşük olmalarından kaynaklandığı ile ilişkilendirmişlerdir (Gürbüz, 2011). Gelir seviyesi az olan kişiler faaliyetlere katılımda bir eğitmen tutamadıklarından ve aktiviteleri nasıl ve nerede gerçekleştirecekleri hakkında bilgi sahibi olmamalarından dolayı, daha fazla gelir seviyesine sahip olan. Böylece düşük gelir düzeyine sahip bireylerin aktivitelere katılımlarına engel teşkil ettiği söylenebilir. Burton, Turrell ve Oldenburg (2003) araştırmalarında katılımcıların gelir düzeylerinin rekreasyonel faaliyetlere katılımı önemli derecede etkilediğini ifade etmektedirler (Turrell, 2003). Aynı şekilde Taylor ve Gratton un (2002) gerçekleştirdikleri araştırma neticesinde yüksek gelir seviyesine sahip bireylerin rekreasyonel etkinliklere katılımda önemli bir yeri olduğunu ifade etmektedir (Taylor, 2002).

Önal'ın (2017) “Atatürk Üniversitesi Öğrencilerinin Boş Zaman Tutumları İle Boş Zaman Aktivitelerine Katılımını Engelleyen Faktörlerin İncelenmesi” araştırmasında katılımcıların duyuşsal ve bilişsel olarak tutumları incelendiğinde; genel olarak tesis boyutunun engellediği yönünde bulgulara rastlansada davranış boyutunda, tesislerin yetersiz veya aşırı kalabalık olmasının bir engel teşkil etmediğide görüşmüştür. Böylece boş zaman aktivitesi sportif, sosyal, sanatsal veya kültürel aktivite olsun bireyler; yeni bilgi ve beceri açısından farklılık yaratmak için aktivitelere katıldıkları tesislere önem vermekte; daha önceden gerçekleştirdiği aktivitelere katıldıysa veya başka alternatif yerlerde de aktiviteleri gerçekleştirebileceğini düşünüyorsa birey için tesisin önemi fazla yoktur. Boş zaman faaliyetlerine karşı duyuşsal ve bilişsel tutuma sahip bireylerin gerçekleştirilen aktivitelere karşı oluşabilecek olumsuzlukları gideremedikleri; davranışsal bakış açısına sahip bireylerin, gösterdikleri tutumları sayesinde olumsuz durumları ortadan kaldırdıkları görülmüştür (Önal, 2017).

Akyüz (2015) araştırmasına katılan öğrencilerin çalışma durumlarına göre tutumları değerlendirildiğinde, öğrencilerin çoğunluğu \%77'si çalışmadığını, daha sonra sırası ile \%13,5'i sadece yaz tatilinde çalıştığı, \%4'ü part time veya hafta sonu çalıştığı, \%3'ü kısmen kendi işini yaptığı ve \%2,3'ü tam zamanlı çalıştı̆̆ cevabını vermiştir (Akyüz, 2015). Öğrencilerin çalışıp çalışmama durumlarına göre tam gün çalışanların ortalamaları duyuşsal alanda en yüksek, en düşük hafta sonu veya part time çalışanlar, bilişsel alanda en yüksek tam zamanlı çalışanlar, part time çalışanlar en düşük, davranışsal alanda tam gün çalışıyorum en yüksek, hafta sonu veya yarım gün çalışıyorum en düşük, toplamda en yüksek tam zamanlı çalışanlar, part time çalışanlar en düşük olarak bulunmuştur. Yapılan analizler sonucunda bilişsel, duyuşsal ve davranışsal alan ve genel tutum düzeyinde anlamlı farklılık gözlenmemiştir. Akyüz (2015)'ün boş zaman tutumlarına yönelik davranışsal alt boyutu harici diğer alt boyutlar ve genel tutum düzeylerinde benzerlik görülmüştür. Bakay (2018)'nn araştırmasında öğrencilerin bir işte çalışıp çalışmama durumlarına göre boş zaman tutum düzeyleri arasında anlamlı farklılık olmadığı görülmüştür (Bakay, 2018). Mevcut çalışmada ise boş zaman tutum değişkeninin davranışsal alt boyutunda anlamlı düzeyde bir farklılık olduğu tespit edilmiştir. Yapılan çalışmalarla hem paralellik hemde zıtlık gösterdiği görülmektedir.

Sonuç olarak; üniversite öğrencilerinin boş zaman faaliyetlerine karşı tutumları incelendiğinde, öğrencilerin boş zamana karşı tutumlarının (cinsiyet, bölüm, çalışma durumu ve aile gelirlerine göre) farklılaştığı tespit edilmiştir. Öğrencilerin cinsiyetlerine göre farklı boş zaman tutumlarına sahip olmalarının tespit edilmesi ile üniversitelerde kız ve erkek öğrenciler için farklı boş zaman etkinlikleri düzenlenebilir. Öğrencilere sosyal faaliyet imkânı sağlarken cinsiyetlerine göre ihtiyaçlarını değerlendirilmesi gerekmektedir. Üniversitenin ve yerel yönetimin öğrencilerin 
boş zamanlarını değerlendirmelerine yönelik hali hazırda var olan tesisleri tekrardan gözden geçirip düzenlemeler yapılabilir. Öğrencilerin bölümlerine göre boş zaman tutumlarına bakıldığında rekreasyon ve antrenörlük eğitimi bölümlerinin diğer bölümlere göre daha fazla boş zaman tutumlarına sahip olduğunu göz önünde bulundurursak, Spor bilimleri fakültesinde boş zaman tutumları düşük olan beden eğitimi ve spor öğretmenliği ve spor yöneticiliği bölümleri müfredatlarında rekreasyon ve boş zamana yönelik derslerin arttırılması ayrıca öğrencilere bu konu ile ilgili panel, söyleşi, seminer vb. eğitimler verilebilir. Öğrencilerin çalışma durumlarına göre boş zaman tutumlarına bakıldığında davranış boyutunda farklılık olması çalışan öğrencilerin işlerinden ve derslerinden zaman ayırabilmeleri ile ilgili olduğu düşünülmektedir. Öğrencilerin aile gelir durumlarına bakıldığında, gelir seviyesi düşük olan ile orta olan arasında fark görülmektedir. Bu durumda gelir seviyesi düşük olan öğrencilerin boş zaman tutumlarının da orta seviye olandan daha az olmasından dolayı özellikle yerel yönetimler ve işletmelerin düşük gelir seviyesinde olan öğrencilere yönelik boş zaman aktivite hizmeti sunmaları gerekmektedir.

Araştırmada öğrencilerin boş zaman faaliyetlerine yönelik tutumlarının bazı demografik değişkenlere göre karşılaştırılması yapılmıştır, gelecek çalışmalarda öğrencilerin tutumlarının yanı sıra katılım gösterdikleri aktivite çeşitleri, aktivite sıklık ve süreleri dikkate alınarak gerekli farklılık ve ilişkiler tespit edilerek gerek üniversitelere gerek yerel yönetimlere önerilerde bulunula bilinir.

\section{Kaynakça}

Akgül, B. M., \& Gürbüz, B. (2011). Boş Zaman Tutum Ölçeği: Geçerlik ve Güvenirlik Çalışması, Gazi Beden Eğitimi ve Spor Bilimleri Dergisi, 16(1), 37-43.

Akgül, B. M. (2011). Farkl kültürlerdeki bireylerin boş zaman aktivitelerine yönelik tutumlarının değerlendirilmesi: Ankara-Londra örneği. Yayınlanmamış Doktora Tezi, Gazi Üniversitesi Sağl1k Bilimleri Enstitüsü.

Akyüz, H. (2015). Üniversite öğrencilerinin boş zaman faaliyetlerine yönelik tutumlarının incelenmesi: Bartın üniversitesi örneği. Yayınlanmamış Yüksek Lisans Tezi Bartın Üniversitesi, Eğitim Bilimleri Enstitüsü.

Aslan, L. N. (2000). Üniversite öğrencilerinin boş zaman değerlendirme eğilimi: öğretmen yetiştiren kurumlarda karşılaştırmalı bir araştırma. Ege Üniversitesi Eğitim Fakültesi.

Bakay, M. (2018). Ortä̈ğretim öğrencilerinin boş zaman faaliyetlerine yönelik tutumlarının belirlenmesi. Yayınlanmamış Yüksek Lisans Tezi, Batman Üniversitesi Sosyal Bilimler Enstitüsü.

Broadhurst, R. (2001). Managing environments for leisure and recreation. Psychology Press.

Burton, N. W., Turrell, G., \& Oldenburg, B. (2003). Participation in recreational physical activity: why do socioeconomic groups differ?. Health Education \& Behavior, 30(2), 225-244.

Büyüköztürk, Ş., Çakmak, E.K, Akgün, Ö.E., Karadeniz, Ş. \& Demirel F. (2019) Eğitimde Bilimsel Araştırma Yöntemleri. 27. Baskı, Pegam Akademi.

Min-Hau, C., \& Phillips, D. A. (2002). The relationship between attitude toward physical education and leisure time exercise in high school students. Physical Educator, 59(3), 126.

Deng, J., Walker, G. J., \& Swinnerton, G. (2005). Leisure attitudes: A comparison between Chinese in Canada and Anglo-Canadians. Leisure/Loisir, 29(2), 239-273.

Gümüş H., Ayna Ç., \& Yıldırım İ. (2018). Reviewing attitudes of women towards leisure activities in terms of different variables. Turkish Journal of Sport and Exercise, 20(3), 224-229. 
Gürbüz, B., Yenel, F., Özdemir, A. S., Akgül, B. M., \& Karaküçük, S. (2011). Türk Toplumunun Boş Zaman Değerlendirme Profili: Ankara İli Örneği. Gazi Beden Eğitimi ve Spor Bilimleri Dergisi, 16(4), 41-51.

Karaküçük, S., Kaya, S., \& Akgül, B. M. (2016). Rekreasyon bilimi. Ankara: Gazi Kitabevi.

Karaküçük, S., Yenel, F., Gürbüz, B., Özdemir, S., Demirel, M., Sarol, H., \& Karaküçük, B. M. (2008). Türk toplumunun boş zaman davranış profilleri ve rekreasyonel etkinliklere katılımdaki engeller: Ankara ili örneği. Gazi Beden Eğitimi ve Spor Bilimleri Dergisi, ISSN: 1304-2408.

Karaküçük, S. (1999). Rekreasyon Boş Zamanları Değerlendirme, 4. Baskı, Gazi Kitabevi.

Karasar, N. (2005). Bilimsel Araştırma Yöntemi. Nobel Yayın Dağıtım.

Karakullukçu, Ö. F. (2020). Öğretmen Adaylarının Boş Zaman Tutumlarının İncelenmesi, Spormetre, 18(1), 2020, 264-272

Karataş, N. Y. (2006). Yatılı ilköğretim bölge okullarında okuyan öğrencilerin boş zamanlarını değerlendirme alışkanlıkları (Bingöl İli Örneği). Yayınlanmamış Yüksek Lisans Tezi Uludağ Üniversitesi.

Kılbaş, Ş. (2010). Rekreasyon (Boş Zamanı Değerlendirme), Gazi Kitabevi, 4. Baskı.

Önal, L. (2017). Atatürk Üniversitesi Öğrencilerinin Boş Zaman Tutumları İle Boş Zaman Aktivitelerine Katılımını Engelleyen Faktörlerin İncelenmesi, Erzurum.

Ragheb, M. G., \& Beard, J. G. (1982). Measuring leisure attitude. Journal of leisure Research, 14(2), 155-167.

Sanin, B. (2019). Türkiye'deki Meslek Yüksekokulları Spor Yönetimi Programı Öğrencilerinin Boş Zaman Faaliyetlerine Yönelik Tutumlarının Incelenmesi. Yayınlanmamış Yüksek Lisans Tezi Sağlık Bilimleri Enstitüsü, Marmara Üniversitesi.

Taylor, P., \& Gratton, C. (2002). The economics of sport and recreation: an economic analysis. Routledge.

Yıldıran, M.A. (2019). Üniversite Öğrencilerinin Boş Zaman Tutum Düzeylerinin Boş Zamanda Sikılma Algısının Belirlenmesindeki Rolünün İncelenmesi. Yayınlanmamış Yüksek Lisans Tezi, Kırıkkale Üniversitesi, Sağlık Bilimleri Enstitüsü.

Wilson, J. (1980). Sociology of leisure. Annual Review of Sociology, 6(1), 21-40. 